\title{
Public and Journalist Perception in Surakarta about Covid-19 News Model
}

\section{Persepsi Masyarakat dan Wartawan di Surakarta tentang Model Pemberitaan Covid-19}

\author{
Erwin Kartinawati ${ }^{1}$, Betty Gama ${ }^{2}$ \\ ${ }^{1}$ Universitas Sahid Surakarta, Jl Adi Sucipto 154, Surakarta \\ ${ }^{2}$ Universitas Veteran Bangun Nusantara, Jl Letj.Sujono Humardani No.1, Sukoharjo \\ *Corresponding author, e-mail: erwinpurwasito@gmail.com
}

\begin{abstract}
Mass media adds anxiety to the community regarding Covid-19 news. Some chose not to consume news or did other kinds of counters to reduce the anxiety effect. This study investigated the perception of the public and journalists in Surakarta about Covid-19 news and their perception about the ideal reporting model in a situation such as this time. Agenda setting media theory was used to understand the issue explored. Data were collected using questionnaire and interview. This research concluded that media was considered a cause of psychological disorders, especially anxiety and fear, because of the bad news. The media was still not sensitive to public needs as news tends to pursue ratings/compete to find viewers by making excessive or bombastic titles. The expected news model shall prioritize facts and minimize the negative impact through optimistic news; educational; clear and complete information by credible sources; used terms that were understood by all; showed empathy, sympathy; and content variation.
\end{abstract}

Keywords: Covid-19; Disaster, Journalist; News Model; Perception

\begin{abstract}
Abstrak
Media massa menyumbang rasa cemas masyarakat terkait berita Covid-19. Sebagian memilih tidak mengonsumsi berita atau melakukan bentuk konter lain demi mengurangi efek cemas. Kajian ini berisi pandangan masyarakat dan wartawan di Surakarta mengenai pemberitaan Covid-19, serta pandangan mereka tentang model pemberitaan yang ideal dalam situasi seperti ini. Teori agenda setting media digunakan untuk membantu memahami persoalan digali. Data didapat melalui kuesioner dan wawancara. Hasilnya, pemberitaan media disebut sebagai penyebab terjadinya gangguan psikologis terutama rasa cemas dan takut. Hal itu disebabkan media lebih banyak mengedepankan berita negatif/kabar buruk. Media dianggap belum peka terhadap kebutuhan publik berkat pemberitaan yang cenderung mengejar rating/berlomba-lomba mencari viewers dengan membuat judul berlebihan atau bombastis. Model berita diharapkan adalah yang tetap mengedepankan fakta namun juga mampu meminimalisir dampak melalui berita yang menguatkan, menumbuhkan optimisme, mengedukasi, informasi jelas dan lengkap dari sumber kredibel, penggunaan bahasa yang dipahami semua kalangan, berita yang menujukkan empati, simpati, serta variasi konten.
\end{abstract}

Kata Kunci: Bencana; Covid-19; Jurnalis; Model Pemberitaan; Persepsi 


\section{Introduction}

The coronavirus disease or Covid-19 that attacks all aspects of the world impacts people's lives, both to material and non-material matters. The presence of this new type of virus for which no cure has yet been found makes people anxious, frightened, and even depressed. In Indonesia, the first positive case for coronavirus was submitted by the president in early March (Ihsanuddin, 2020). Covid-19 coverage in the mass media must be recognized as contributor to the psychological situation of the society. Some are increasingly anxious, have trouble sleeping, and even fall sick. In addition, media coverage has also triggered a movement of behavior and attitudes in the community, starting from isolating public members and their families exposed to the coronavirus either as Person under surveillance (ODP), Patients under surveillance (PDP), and Person of positive Coronavirus. In some regions, there have even been rejections to the corpses of the victims of coronavirus disease (P. Kurniati, 2020).

The news about the increasing number of deceased victims increasingly alarmed the community. The call to stay at home through the media also encourages panic buying, which causes the scarcity of some materials needed by the community, including being used by hoarders for personal gain. Frame media that show Covid-19 is a severe problem and needs to be watched out for, making many public members choose not to watch the news to get peace of mind, which is needed to maintain the immune system. The emergence of the challenge "until tomorrow", in which people are posting the nastiest poses on social media to bring out the laughter, then the challenge of presenting a variety of dishes, hobbies, and other exciting things by the public through social media, are some forms of counter to mass media coverage which is still considered "creepy" for people's mental health. Not only residents, even journalists highlight media coverage still primarily concerned with the comparison of the number of patients who have died and recovered, then blaming the government and raise its shortcomings in handling Covid-19. A number of media are still considered insensitive to the situation and its impact on the public so that it is considered still competing so that the public can read the news through bombastic titles. This is in line with a journalist's argument in Surakarta through his social media (Facebook), March 29, 2020.

The background above shows the anxiety of the public as well as journalists about media coverage. This paper is expected to offer an ideal reporting model according to the expectations of the public and journalists in situations of the Covid-19 disaster, as well as other forms of disasters at other times so that the content and methods of the media in reporting events not only cause public anxiety and anxiety but also have a calming effect, without having to cover the real facts on the ground. There are two things discussed in this paper: the public and journalists' perception about Covid-19 news and the kind of news model expected by the public and journalists. A number of parties have conducted studies on disaster coverage in the mass media. Some of them are even summarized in a book entitled "Media, Journalism, and Disaster Communities" (Matthews and Thorsen, 2020). The book summarizes the ideas of community members who are affected or vulnerable to disasters such as what has happened in Brazil, Nepal, Japan, Myanmar, Nigeria, and several other cities. The study focuses more on local media's ability to voice up the voices of the affected communities as part of decision making during and post-disaster management. Unfortunately, local media is said to be a failure because it is unable to raise issues that are actually a public concern. Research on disaster journalism by Sukmono and Junaedi (2018) was 
conducted in relation to disaster communication problems experienced by journalists covering the 2010 Merapi eruption in the Yogyakarta region. In conclusion, journalists are required to have the ability to present accurate data and verify sources in order to produce disaster sensitive products. Thus, the media is able to provide hope to the affected residents and audiences through optimistic journalism in disaster coverage. Redi Panuju also reported on disaster journalism (2018). The destination highlighted Balipos.com's news during the 2017 Mount Agung disaster. The results of the study showed that Balipost.com's report was lacking in depth and having minimal direct observation. This current study, however, is different from the three research examples above. Matthews and Thorsen highlighted the role of local media, Sukmono and Junaedi focused on communication issues for journalists covering disasters, while Panuju focused on the ethical aspects of the mass media. This study seeks to reveal the reporting model during times of disaster, especially Covid-19, based on the expectations of the community and also the journalists' side. This study explores the public and journalists' perceptions regarding the news model that the public wants without ignoring the actual facts, but is able to reduce the effects of anxiety and foster public optimism that this pandemic can be passed well.

\section{Method}

The data in this study was collected by distributing questionnaires and conducting interviews with the public and journalists in the Surakarta area. As the Covid-19 pandemic that has not ended, interviews were not conducted directly but using intermediaries; namely google form, telephone, and private conversation services. There is no specificity on age, education level, social, economic, or another status in determining respondents/informants. The data results were processed quantitatively and qualitatively by describing the expected perceptions and models related to Covid-19 news. From this, it can be said that this research uses a combination method. The quantitative method is the primary method, while the qualitative method, through the interview, is a supporting method to fill in the gaps in the data obtained quantitatively (Kriyantono, 2010); (Birowo, 2011). Interviews were not carried out on all respondents but were selected based on the need to complete the questionnaire's data. The questionnaire was distributed via google form on April 1-5, 2020. The number of respondents was 145 people. Of these, 20 of them are active journalists.

\section{Results and Discussion}

In this study, the respondents to fill out the questionnaire are those accustomed to mass media/news exposure, including teachers/lecturers, state civil servants, private employees, and a few homemakers. The respondents are differentiated from other professions such as farmers, traders, or marginalized groups who usually rely on information sources from figures, word of mouth communication, or non-intense mass media users (not the primary source). The thesis in communication studies states that if community members are educated and have sufficient income, they are more information literate than the less educated and low-income groups. The history of mass media in Indonesia is also supported by educated and well-paid circles which have led to literacy (Sunarti, 2013). This research still strengthens this thesis, seen from the percentage of respondent sources in obtaining information about Covid-19. Of the 145 people, $66.9 \%$ revealed that they received information from mass media, social media (71.7\%), government officials $(24.1 \%)$ and public figures $(11 \%)$. These respondents are 
members of the public who consume no information only from one medium but also from other sources. It is tough to separate the use of information sources between old media and new media in the current digital era, considering that media management has also converged. Their ages ranged from 21 to 58 years with almost equal sex, namely 75 men $(51.72 \%)$ and 70 women $(48.28 \%)$. These respondents stated that the news about Covid-19 harmed their psychological side. Covid-19 news makes people anxious, anxious, stressed, even afraid. A small proportion of them experiences sleep disturbances to fall ill. Very few would answer if media coverage of this outbreak had no impact (see figure 1).

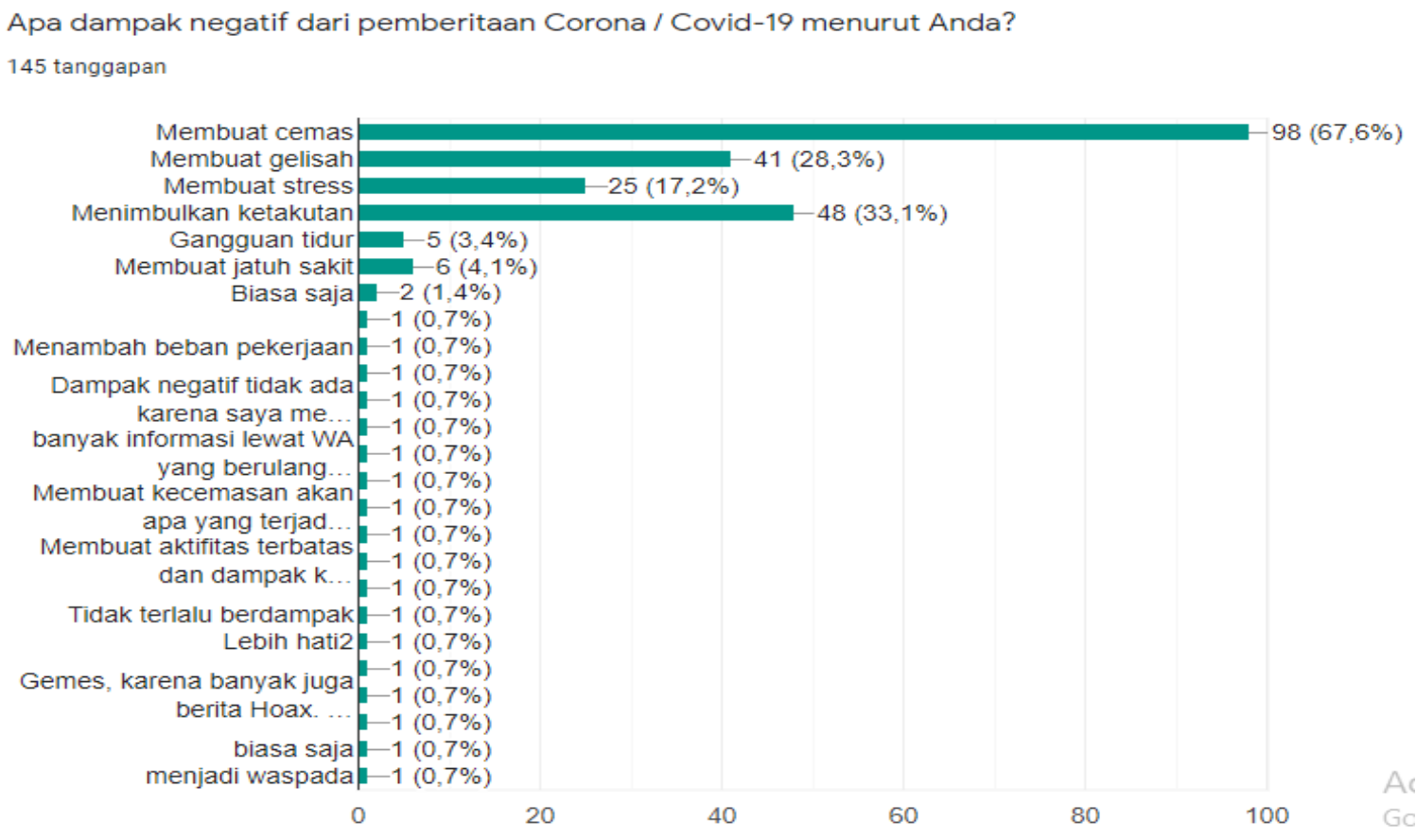

Figure 1. Screenshot of Table on the Negative Impact of Covid-19 Reporting on Community Psychology (source: Researcher data)

However, despite reporting the negative impact of Covid-19, media also encourages people to adopt a culture of clean and healthy living, increases awareness, and increases their understanding of the dangers/effects of the disease. Regarding the culture of clean and healthy living, what is meant is that the community becomes more concerned and aware of the importance of washing their hands appropriately, the importance of consuming fruits and vegetables, and the consumption of balanced types of food and exercising. Regarding the increased awareness of the community and public understanding, an attitude of anticipation from the community is encouraged by looking for information sources to prevent and avoid the disease. Based on Figure 1, we can conclude that the coronavirus news must be recognized as the most significant contributor to people's anxiety. Anxiety is triggered because the media are considered not or less sensitive to the psychological condition of society. Ironically, the public considers the news about Covid-19 is as a means to exploit profit from the media, in this case, to pursue ratings and/or to increase the number of readers/viewers visit $(33.1 \%)$. This is based on the respondent's assessment of the media's tendency to present negative news and/or contain horror elements (22\%). 
The choice of bombastic or excessive news headlines strengthens society's growing judgment regarding how the media works, which prefers to look for bad things, since bad news is good news (see Figure 2). In making news about Covid-19, the media is also considered less clear because they only prioritize speed so that much information is presented in fragmented, incomplete, or less comprehensive ways. This is also an impact of the strategy to increase ratings / attract viewers. The mass media are also considered to present news from only one source, which results in incomplete and unclear information presented to the public. However, some people also think that the news in the mass media about Covid-19 has met the minimum requirements as contained in journalism's basic principles, namely accurate, balanced, objective, and transparent. What is shown in Figure 2 is the general public perception regardless of the respondent's background/profession.

Bagaimana pendapat Anda tentang pemberitaan di media massa (koran, televisi, radio, internet) tentang Corona?

145 tanggapan

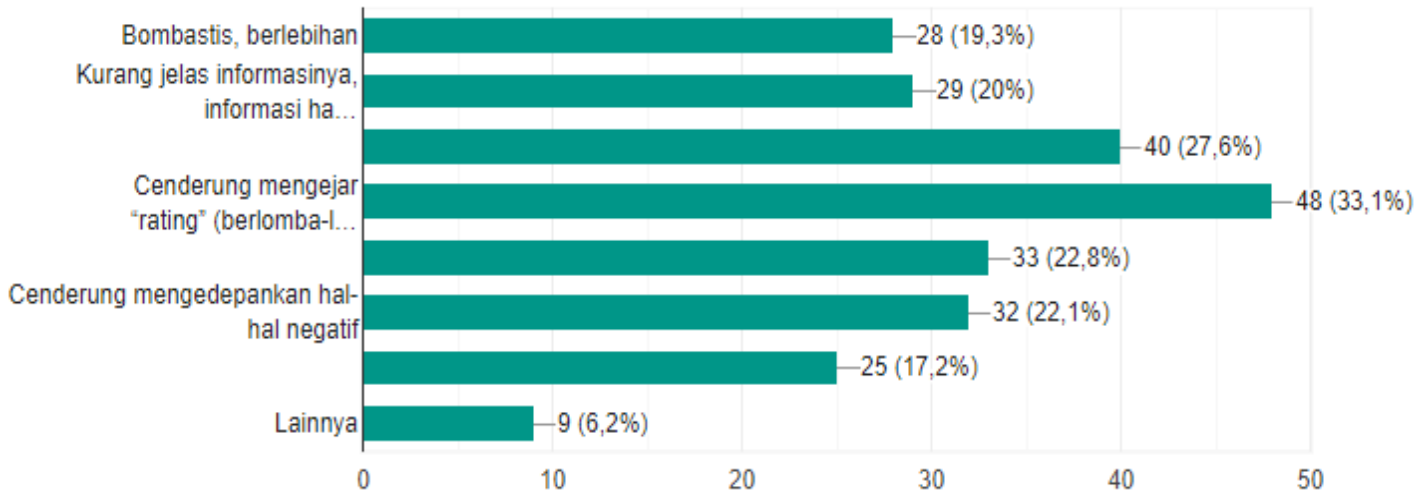

Figure 2. Screenshot of Table of Community Assessment of Mass Media Coverage (source: Research data)

So, how do journalists or media actors perceive mass coverage of Covid-19? Does it also harm the psychological side, and do they tend to be optimistic about media coverage quality? In this question we will see how media actors judge their own groups. Of all the journalists who gave their views on mass media coverage of Covid-19 (20 people), they turned out to have experienced the same psychological "attack" as ordinary members of society, who were not involved in media coverage. All journalists said that mass media coverage also made them anxious, anxious, and caused fear. They experience this psychological disorder because, according to some journalists, when asked further about the causes, they cannot avoid choosing information outside of Covid-19 whether they like it or not. Not only do they get a "rush" of information from related sources, but they also have to find information about the latest developments in the Covid-19 case in the areas they handle. Seeking and obtaining direct information emphasize that it is different from people who only receive information based on media coverage. They are overshadowed by anxiety, worrisome, and fear due to continuous information about the negative impacts of the covid-19. They are also highly risking their lives contracting a disease that has not yet been found a cure. Besides, they cannot get the privileges as ordinary people are asked to stay at home and carry out social distancing as recommended by the government. 
Then how do they view the mass media coverage about Covid-19? Of the 20 journalists, only eight people assessed if the news about Covid-19 had fulfilled the basic principles of journalism or only 40 percent. This means that more than half of media actors assess that there is something that deserves to be evaluated regarding how the mass media reports information, especially regarding Covid-19. The basic principles of journalism in media coverage are not fulfilled, again because there are still many news stories that only contain information from one source, not complete/comprehensive. This makes the news less complete and less clear when presented to the public. There are still many news models that prioritize speed so that they ignore accuracy and balance as well as other completeness so that the information obtained by the public is only fragmentary, incomplete, and less complete. What is in the spotlight is that there are still many media that are actually taking advantage of this urgent situation to reap profits from the number of readers' visits or the number of viewers by making bombastic news, making excessive headlines, and presenting things that cause horror at the community level. Disaster reporting that exploits disaster as a business commodity is not a new phenomenon. Dramatization and bombastic news also occurred in the coverage of the Aceh tsunami in 2004 and Merapi eruption in 2006. Muzayin Nazaruddin (2007: 163-177) said this happened because the media neglected to use the principles of good journalism related to news euphoria, which had high news value. The stereotype that bad news is good news is still strong. The media carries out grief coverage, but on the one hand, they also carry out a joyful function, which is exemplified by the broadcast of the new year's party highlights. That is what is called the ambivalence of the media function.

In the Covid-19 disaster, we saw the media reporting many deaths and also other social impacts due to the disaster. However, on the one hand, the media actually displayed the activities of artists spending time at home related to calls for social distancing, which was in stark contrast to the lives of the lower class started having difficulty eating due to not being able to work and earn money like normal days. Nazaruddin added that the media were never consistent in reporting in the sense of continuous reporting. The news is presented in pieces so that it is neither complete nor profound. The situation is in fact the same, and we can see it in our current media coverage. Masduki made a similar criticism (2008). Reports on disasters are always focused on traumatic and dramatic things in nature, containing sobs and expressions of sorrow on the pretext of fostering solidarity. In the current context, we see the same problem where the number of victims died and the emergency is the central exploitation under the pretext of growing and maintaining public awareness, tracing the research results as in Table 1. In this kind of situation, the press is actually also required to participate in the cause of disaster management, which relies not solely on the ability to provide material assistance but also in the form of moral support (Susanto, 2011). From the perspective of disaster sensitive journalism, the mass media is a crucial element when a disaster occurs. Disaster sensitive journalism is a journalism practice that contains much information and moral messages and does not cause panic or dramatization of the disaster. However, idealism regarding disaster-sensitive journalism is not an easy matter because of many factors such as the demand for actuality, the reporter's capability, and the media's awareness of the public interest. (Sukmono, Filosa Gita; Junaedi, 2018). 
Table 1. Journalists' Perceptions of Covid-19 Coverage

(source: Research data processing)

\begin{tabular}{clc}
\hline No. & \multicolumn{1}{c}{ Journalists' Perceptions } & Number of Answers \\
\hline 1. & Generates worry & 13 \\
\hline 2. & Generates anxiety & 7 \\
\hline 3. & Trigger fear & 2 \\
\hline 4. & Trigger stress & 8 \\
\hline 5. & $\begin{array}{l}\text { It is good according to the basic principles of } \\
\text { journalism }\end{array}$ & 4 \\
\hline 6. & Bombastic, excessive & 3 \\
\hline 7. & $\begin{array}{l}\text { Less clear information, information only } \\
\text { fragmentary / incomplete / fragmented }\end{array}$ & 3 \\
\hline 8. & $\begin{array}{l}\text { Information tends to be only from one side } \\
\text { so it is lacking comprehensive (complete and } \\
\text { clear) }\end{array}$ & 9 \\
\hline 9. & $\begin{array}{l}\text { Tend to chase "rating" (competing to be read } \\
\text { / viewed by the audience / viewers) }\end{array}$ & 3 \\
\hline 10. & Tends to put forward horrific things \\
\hline 11. & $\begin{array}{l}\text { Tend to put forward negative things /bad } \\
\text { news }\end{array}$ & 4 \\
\hline
\end{tabular}

From the Table above, we can see that the news about Covid-19 harms the psychological side of the public as well as journalists. So, news model like what do journalists want? Of the 20 journalists whom we asked for their responses, they answered that the ideal news in a disaster situation is news that still puts forward facts by presenting it according to the basic principles of journalism but also making efforts to minimize the negative impacts that arise from the news, such as reducing the anxiety caused by the bombardment of bad news related to Covid-19. Another way done is not only to emphasize the destructive effects of the dangers of Covid but also how to fight this virus.

"The other side of Covid-19 must be reported, but it all depends on us as journalists. Where do you want to be taken to this tense situation. Facts are still facts, but choose a point that can generate optimism in order to break the pandemic. Never mind, just stop or give a small portion of news about the death toll, the rejection of the corpse, the news about the recovered patient and the news that sparked joy even though it was only a small one", said a national media journalist (informant number 145), April 5, 2020.

Four other journalists ( 3 national media, 1 local media) highlighted the existence of media that highlighted statistical reporting patterns by always comparing the number of victims who died and recovered. Human life, according to them, is not a statistical filler in the news, even though it is a fact that the public needs to know. Facts can indeed raise awareness, but what is more important in a disaster situation like this is not to continue to douse people's minds with scary facts or negative things related to Covid19 or the authorities' inappropriate handling. Presenting facts by minimizing negative effects is emphasized to be far more important. The way that can be done, according to the four of them, is to convey a method that is considered appropriate to be able to avoid viruses. 
"In a situation like now, the press let's make people unite to fight the pandemic. Make the community awake and responsible. Emphasize that this is a joint task, not just the task of a particular party or agency", explained informant number 143, April 5, 2020.

According to several other journalists, the way to make the public rise, maintain and generate public optimism amid this epidemic is not to make news that can have a terrifying effect. Concretely, it is to avoid making headlines that are excessive or bombastic in nature, more so simply to attract readers' interest and curiosity. In a disaster situation like this, journalists say that the press plays a big role in social stability. The appeal to stay indoors and not to come out for a certain period to break the chain of the virus impacts the loss of economic income for some people, especially from the private sector. It is essential for the press to knock on the hearts of the public and continue to make the public aware of the need for concern and empathy for others.

In contrast to the majority of journalists who consider the need to reduce the negative impact of reporting such as the effects of anxiety, anxiety, and fear, two journalists state that the negative impact of such news is something that cannot be avoided. For them, it is very important to present news in accordance with the facts even if it has a terrifying effect on people's minds. Making news according to facts, including negative things, will actually make the public even more alert because there are no facts that need to be covered up. In fact, in a situation like this, it takes the maturity of the community to realize how dire the situation is by not ignoring the appeal of the government / related parties so that this pandemic will end soon.

"We are disappointed because the media are always being blamed. The media is considered the cause of society's anxiety; it is said to always create bad news. The fact is so. Now we see, it has been proven how unruly, insensitive, and indifferent society is. Once we reported positive things, namely when Solo was declared coronavirus free because there were no more positive patients, the streets immediately became busy again. They immediately went out of the house, took a walk. They do not know the real situation. Free does not mean there are no more threats. There are still tens of PDP status and hundreds of ODP. We cannot take holidays or stay at home like other people because of the demands of work. Those of you who only stay at home, help us. We also want a day off; we want to take a break soon. If this goes on, there will never be an end. We are tired. Yes, your immunity is good. But can you bear it if you are hungry, you cannot eat because of the prolonged situation. "wrote journalist informant no.146, part of his resentment he also poured out on his social media (facebook), 2 and 5 April 2020. Furthermore, the journalist / informant number 135 said that good news is not news that contains good things or good news. Good news, according to him, is a news that is true. True news can be justified for its truth through the correct process, which is confirmed and obtained from competent sources. Regarding what the ideal reporting model looks like in a disaster situation in the eyes of a journalist, it is summarized in Table 2 below.

Table 2. Ideal Reporting in Covid-19 Disaster Situations Based on Journalists'

\begin{tabular}{ccc}
\hline \multicolumn{3}{c}{ Perceptions (source: Research data processing) } \\
\hline No. & \multicolumn{1}{c}{ Journalists' Perceptions } & Number of answers \\
\hline 1. & $\begin{array}{l}\text { Continue to uphold the basic principles of } \\
\text { journalism and code of Ethics }\end{array}$ & 20 \\
\hline
\end{tabular}


2. Presenting facts as it is even though it raises 3 anxiety effects and other consequences.

3. Keep reporting the facts by minimizing negative 16 impacts arising from reporting:

- Presents more about understanding the character of the virus, how to handle or prevent, not put forward harm/impact of the virus

- Does not make bombastic / excessive title

- Presenting information that is positive, inspirational, provide solution which generates enthusiasm in citizens to fight together against the coronavirus virus disease

- Fostering a sense of empathy/tolerance in the midst of a pandemic, dissectingmyths/ hoaxes about viruses

- Showing the spirit and solidarity of the people

- Do not conflict/clash things with particular parties

4 Putting forward the good facts (positive news) 1 though covering up the bad facts that actually happened

So what kind of news model do community members expect in a disaster situation or the Covid-19 pandemic? Of the 125 respondents, they wanted news that could suppress feelings of anxiety, worrisome, or things that could reduce their psychological disorders. From the following Table, it can be seen if the citizens expect the media to continue to report facts but still think about the impact on society. In other words, the media are still required to convey facts and minimize the harmful effects that result from the news. On this topic, we provide five answer options, as mentioned below in Table 3. Each respondent can choose more than one option.

Table 3. Public Perception about the Ideal Media of Covid-19

(Source: research data)

\begin{tabular}{clc}
\hline No. & \multicolumn{1}{c}{ Perception } & Number of Answers \\
\hline 1. & $\begin{array}{l}\text { Keep reporting according to facts even though it } \\
\text { raises anxiety and other negative effects }\end{array}$ & 40 \\
\hline 2. & $\begin{array}{l}\text { Putting forward the good facts (positive news) } \\
\text { though covering up the (bad) facts that actually } \\
\text { happened }\end{array}$ & 53 \\
\hline 3. & $\begin{array}{l}\text { Present about how to handle viruses, right on the } \\
\text { dangers and the impacts of the virus }\end{array}$ & 72 \\
\hline 4. & $\begin{array}{l}\text { Keep reporting the facts by minimizing negative } \\
\text { impacts arising from reporting: } \\
\quad \text { News that strengthens, motivates, emerges } \\
\text { optimistic feeling that the pandemic can be }\end{array}$ \\
\hline
\end{tabular}


passed

- Educational news, calming

- Data must be complete $(5 \mathrm{~W}+1 \mathrm{H})$, valid from the reliable source, clarified, accountable.

- Titles are not bombastic; not using excessive language

- No frightening, worrisome, nor anxiety effect.

- Use language that is easy for all people to understand (language for all people)

- Does not continue to report dead victims

- Balance between bad news and news Good news

- News that shows empathy, sympathy, such as social care, don't preach the way rich / artist people spends time in the isolation period

- Need to alternate impressions, not everything about coronavirus

\section{Others}

Meanwhile, out of the 125 , there are four former journalists with a minimum work period of 5 years. We will see their input regarding Covid-19 news. The existence of respondents who are former journalists is an advantage in this study because they are in the middle position, namely between the public and journalists. Even though they are no longer active in the reporting process, they are still very active in following everything related to news, including the way the media reports things, then compare it to a situation where they are still active as journalists.

Table 4. Perceptions of Former Journalists About Covid-19 Coverage (source: Processed research data)

\begin{tabular}{clc}
\hline No. & \multicolumn{1}{c}{ Perception } & Number (Respondents) \\
\hline 1. & Make anxious & 3 \\
\hline 2. & Make restless & 2 \\
\hline 3. & Creates fear & 1 \\
\hline 4. & Increase alertness & 3 \\
\hline 5. & Increase knowledge & 1 \\
\hline 6. & Cultivate / enhance a clean and healthy living culture & 1 \\
\hline 7. & Tend to put forward negative things & 2 \\
\hline 8. & Bombastic, excessive & 2 \\
\hline 9. & $\begin{array}{l}\text { Less clear information, only fragmentary/ incomplete/ } \\
\text { fragmented information }\end{array}$ & 1 \\
\hline 10. & $\begin{array}{l}\text { Information tends to be from one side only so it is less } \\
\text { comprehensive (complete and clear) }\end{array}$ & 1 \\
\hline 11. & $\begin{array}{l}\text { Tend to chase "rating" (competing to be read / seen by } \\
\text { the audience / viewers) }\end{array}$ & 1 \\
\hline
\end{tabular}


Table 5. Perceptions of Former Journalists about Ideal Media Covid-19 Coverage (source: Research data processing).

\begin{tabular}{|c|c|c|}
\hline No. & Perception & $\begin{array}{c}\text { Number } \\
\text { (Respondents) }\end{array}$ \\
\hline 1. & $\begin{array}{l}\text { Putting forward the good facts (positive news) although } \\
\text { covering up the (bad) facts that actually happened }\end{array}$ & 1 \\
\hline 2. & $\begin{array}{l}\text { Keep reporting the facts by minimizing negative impacts arising } \\
\text { from reporting: } \\
\text { - Prioritize public awareness/education for tackling the } \\
\text { coronavirus virus disease } \\
\text { - Foster empathy and social solidarity. News broadcasts } \\
\text { that are not dominated by the issue of coronavirus and } \\
\text { elitist resource persons }\end{array}$ & 4 \\
\hline 3. & $\begin{array}{l}\text { Must comply with the basic principles of journalism: } \\
\text { - Balance in presenting facts } \\
\text { - Include accurate data with competent sources in the } \\
\text { handling } \\
\text { - Fact-based news, data verification, confirmed validly } \\
\text { - Must complete } 5 \mathrm{~W}+1 \mathrm{H} \text { news elements, News photo } \\
\text { complete with complete caption, }\end{array}$ & 4 \\
\hline
\end{tabular}

Although the public's general assessment of Covid 19 coverage still requires evaluation, such as not fulfilling the basic principles of journalism, pretentious, and so on, public confidence in the mass media is still quite high. This can be seen from the respondents' answers about how confident they are in the media's content. However, the figure below can also be a concern considering the number of community members who are not sure or actually have doubts about the media coverage, almost half of all respondents. This is because the data in Table 6 below is not divided between ordinary citizens and journalists, so the large contributors to the sure assessment of the content of the mass media may come from journalists.

Table 6. Community Trust in Media Coverage (source: Research data)

\begin{tabular}{lcc}
\hline \multicolumn{1}{c}{ Assessment } & Total & $\%$ \\
\hline Very confident & 6 & 4.1 \\
Sure & 87 & 60 \\
Not sure & 40 & 27.6 \\
Not sure & 3 & 2.1 \\
Does not matter & 1 & 0.7 \\
Others & 8 & 5.5 \\
\hline Total & 145 & 100 \\
\hline
\end{tabular}

According to the public's perception, the ideal news in a disaster situation is the media's way of reporting something that is not according to public expectations. It is related to many news that residents consider simply to increase the rating or the number of readers' visits by making news with turgid or excessive titles (clickbait journalism). It is ironic to see society in a crisis situation, even though in fact what the public thinks is not the same as the version of the media. Sandra Ball-Rokeach and Melvin DeFleur 
said two situations where the public's dependence on the media for information fulfillment was very high. One, when a media is considered capable of fulfilling needs rather than just satisfying, the second is when there is a problem of stability (Mcquail, 2011). The current situation we experience is a stability problem that has been triggered by health problems, which then spread to economic and social stability. We can see that in a precarious situation like now, the level of media consumption is actually very high. People seem to be competing to find information related to viruses and how to handle them. This can be proven by the change in the behavior of the Indonesian people who "suddenly" like to exercise mainly to sunbathe and consume all kinds of rhizomes because according to information circulating in the media, they can maintain and increase immunity, which is the key to avoiding viruses. The sports and sunbathing habits practiced by Indonesian people between 6 to 8 in the morning have now shifted to around 10 in the morning (Kurniati, 2020); (Nurhidayat, 2020); (Radar Kudus, 2020). In this kind of situation, according to the author, clickbait journalism is unnecessary as it contributes to the effects of trauma triggered by stress, anxiety, fear, and so on in the society, as well as having an impact on the credibility of the media concerned. Clickbait journalism is deliberately created to attract readers by harassing the curiosity that arises from gaps in information between what readers know and what readers want to know. Its characteristics include the mismatch between the title and the content, the use of bombastic terms in the news, especially in the title (Hadiyat, 2019); (Wendratama, 2017). Clickbait journalism is primarily aimed at online media. The problem is not the type of media, but the content and/or the pompous title that is put forward to attract readers. In this kind of situation, the accuracy of the news and the media's credibility is one of the stakes. In a precarious situation like now, the media greatly influences opinion and public behavior. In a situation like this, it is precisely the opportunity for the mass media to regain public trust through credible or trustworthy reporting.

Credible or trustworthy news is quality news. Many experts argue about the requirements for quality news, such as having to contain accurate, balanced, and objective principles. News must contain these three things in addition to taking into account the interests of the community. News is meaningless if the information presented has no interest in improving people's lives (Fachruddin, 2012). John Zaller also put forward the goal for the sake of the life of the community or the people (2003). News must provide basic needs for society with the necessary information and be able to provide updates on public opinion on all critical and major issues. However, this was not fulfilled by the press so much that he proposed a concept about quality news, called the Burglar Alarm Standard. According to the Standard, the news must contain interesting, critical, and urgent information like a burglar alarm that sounds for crucial matters. The Burglar Alarm standard is just one part that is sometimes not fulfilled in the news, such as not paying attention to accuracy issues, prioritizing sensations, and personal matters. News does contain elite interests and how much the media can present information related to public affairs.

The Association for Education in Journalism and Mass Communication (Rubin, 2004) formulates news credibility measuring scale. This covers the aspects of fairness, unbiased, complete, accurate information, violation-free of people's privacy. The scale also pays attention to public interests, separates facts and opinions, can be trusted, and is concerned with public interest, factual, well-educated/trained reporters. UNESCO for Indonesia and the Danish Embassy added elements that must be present in the news apart from the correct, essential aspects concerning the lives of many people as 
mentioned by several sources above, namely that they must be actual (Brandt, Torben; Eric, Sasono; Gunawan, 2001). In the current context, journalism in Indonesia, including disaster journalism, emphasizes actual values, so that some of them neglect other principles such as being accurate, balanced, and objective.

\section{Conclusion}

From the presentations above, we can summarize that the public and journalists share the perception that coverage of Covid 19 by the mass media has a psychological impact, especially anxiety and fear. The expected reporting model, namely news, should prioritize facts but pays attention to the adverse effects mentioned above. The mass media can do this through a reporting model that follow certain guides: (a) It is calming by not making bombastic / excessive titles; (b) The content of the news is more educational in nature with a lot of presenting about the understanding of the character of the virus, ways of handling or prevention, dissecting myths / hoaxes about viruses, not merely promoting the dangers / impacts of the virus; (c) Presenting positive, inspirational, and solution information as an effort to generate enthusiasm in citizens to work together to fight corona by promoting positive news; (d) Fostering a sense of empathy / tolerance in the midst of a pandemic; (e) Showing the spirit and solidarity of the citizens; (f) Not contradicting / clashing things / parties with one another; (g) news that strengthens, motivates, raises a sense of optimism that the pandemic can be passed; (h) Use language that is easily understood by ordinary people (language for all circles); (i) Not regularly reporting on victims of death; (j) A balance between news about bad news and good news; (k) There is a need for alternative broadcasts, not all about corona; (1) Must be in accordance with the basic principles of journalism, namely: valid from reliable sources, clarified / can be justified the truth; balanced in presenting facts; include accurate data with competent sources; verified fact-based news; complete 5W + 1H elements; Photo news complete with clear captions and complete data.

The description above concludes that mass media still has a strong influence on forming perceptions and changes in people's behavior. In a disaster situation like today, the media's influence is getting stronger because the public's dependence on the mass media for information related to the latest developments is also high, as a form of anticipation and increasing awareness of problems. However, the effect of media coverage must be recognized as having an impact that is not entirely expected by the public, namely psychological disorders as described above. This is because the media are still considered to present more negative or bad news than encouraging. The public still considers the stereotype that bad news is good news as something attached to the image of the media. Media image in a disaster situation is actually at stake because it impacts public confidence in media content. This is related to the credibility of the media in presenting the content, which cannot be separated from how journalists get facts and how facts are processed as a commodity. It is undeniable that the mass media do indeed carry out a social function as a source of information and the functions of education, entertainment, and social control. However, the function of the media as a business institution inevitably has to make the media adopt a strategy so that the information presented can generate profits. It can be in the form of increased circulation, rating, and the number of site visits. The irony is that the public still considers how the media is used not as something they want because it still sells sensation, is bombastic, puts forward negative things, and increases the rating/number of viewers. Most of the media actors also agree with the opinion of the community. This 
condition certainly has to be a joint evaluation to create ideal news, referring to input from members of the public and the journalist community. Apart from the various perceptions regarding ideal news related to Covid-19, most journalists and members of the public want the mass media to present facts, prioritize actuality, and maintain conduciveness in the field through soothing news.

The news that is needed in the current situation is news that puts forward the facts but still pays attention to the adverse effects of anxiety that are now haunting the public. The application of basic journalistic principles, such as being accurate, balanced, objective, and complying with other ethical codes, must be used as a guide to create credible or accountable media content. The management of mass media, which is now converging with social media, can make the impact of anxiety at the community level even more unstoppable if the expectations of news as desired by the public are not fulfilled, considering that the position of social media can now be juxtaposed with mass media in providing information. Calmness is needed to maintain and improve the people's immune system to avoid corona malignancies. The press has a role in handling outbreaks in this country by creating a conducive climate without having to abandon the facts so that calamities in this beloved country will soon pass. This research still creates gaps in terms of the number of perception givers and the lack of representation of other parties so that the perception of ideal news about Covid-19 can accommodate all parties, such as from the government, police, and also medical personnel. The perceptions of the three actors also need to be explored to obtain a complete formula to support the resolution of the outbreak and post-disaster management.

\section{References}

Birowo, M. A. (2011). Metode Campuran (Mixed Methods), Metode Penelitian Alternatif. In Mix Methodology dalam Penelitian Komunikasi. ASPIKOM.

Brandt, Torben; Eric, Sasono; Gunawan, A. (2001). Jurnalisme Radio: Sebuah Panduan Praktis. Unesco Indonesia bekerjasama dengan Kedutaan Besar Denmark.

Fachruddin, A. (2012). Dasar-Dasar Produksi Televisi: Produksi Berita, Feature, Laporan Investigasi, Dokumenter, dan Teknik Editing. Jakarta: Prenada Kencana Media Group.

Hadiyat, Y. D. (2019). Clickbait on Indonesia Online Media. Jurnal Pekommas, 4(1), 1-10. Retrieved from jurnal.kominfo.go.id > article > download > pdf \%0A

Ihsanuddin. (2020). Fakta Lengkap Kasus Pertama Virus Coronavirus di Indonesia. Retrieved from Kompas.com, 03/03/2020, 06:31 WIB website: https://nasional.kompas.com/read/2020/03/03/06314981/fakta-lengkap-kasuspertama-virus-coronavirus-di-indonesia?page $=$ all\%0D

Kriyantono, R. (2010). Tehnik Praktis Riset Komunikasi. Jakarta: Prenada Kencana Media Group.

Kudus, R. (2020). Dianggap Bisa Tangkal Virus Korona, Jahe Merah Diserbu Warga. Retrieved from Jawa Pos Radar Kudus, 05 Maret 2020, 14: 03: 43 WIB website: https://radarkudus.jawapos.com/read/2020/03/05/182313/dianggap-bisa-tangkalvirus-korona-jahe-merah-diserbu-warga

Kurniati, P. (2020). Ironis, Pemakaman Korban Coronavirus Ditolak dan Ambulans Diusir di Sejumlah Daerah, Mana Saja? Retrieved from Kompas.com website: https://www.msn.com/id-id/berita/nasional/ironis-pemakaman-korbancoronavirus-ditolak-dan-ambulans-diusir-di-sejumlah-daerah-mana-saja/arBB11Z08o?ocid=spartandhp\%0D 
Kurniati, R. (2020). Jahe, kunyit, Lengkuas dan Serai Ikut-ikutan Naik Harga, Pedagang: Tetap Diserbu Pembeli. Retrieved from Tribunpadang.com, Jumat, 20 Maret 2020 17:02 website: https://padang.tribunnews.com/2020/03/20/jahekunyit-lengkuas-dan-serai-ikut-ikutan-naik-harga-pedagang-tetap-diserbupembeli\%0D

Masduki. (2007). Setahun Berita Gempa: Perjuangan Melawan Lupa. Jurnal Media, Jurnalisme Dan Budaya Populer, 240-244.

Matthews, J., \& Thorsen, E. (2020). Introduction: Media, Journalism and Disaster Communities. In Media, Journalism and Disaster Communities. https://doi.org/10.1007/978-3-030-33712-4_1

Mcquail, D. (2011). Teori Komunikasi Massa (6th ed.). Jakarta: Salemba Humanika.

Nazaruddin, M. (2007). Jurnalisme Bencana: Sebuah Tinjauan Etis. Jurnal Komunikasi, 1(2), 163-177. Retrieved from https://journal.uii.ac.id/jurnalkomunikasi/article/view/5254

Nurhidayat. (2020). Dipercaya Mampu Menangkal Virus Coronavirus, Harga Jahe Merah Melonjak Dua Kali Lipat. Retrieved from TimesIndonesia website: https://www.timesindonesia.co.id/read/news/255178/dipercaya-mampumenangkal-virus-coronavirus-harga-jahe-merah-melonjak-dua-kali-lipat\%0D

Panuju, R. (2018). Etika Jurnalistik dan Jurnalisme Bencana pada Pemberitaan Gunung Agung di Portal Berita Balipost.com. Jurnal ILMU KOMUNIKASI, 15(2), 219132. https://doi.org/10.24002/jik.v15i2.1455

Rubin, A. M. (2004). News Credibility Scale. In Communication Research Measures: A Sourcebook (p. 237). Lawrence Erlbaum Associates Publishers.

Sukmono, Filosa Gita; Junaedi, F. (2018). Menggagas Jurnalisme Optimis dalam Pemberitaan Tentang Bencana. Jurnal Ilmu Komunikasi, 15(1), 107-120. Retrieved from https://ojs.uajy.ac.id/index.php/jik/article/view/882/1156

Sukmono, F. G., \& Junaedi, F. (2018). Jurnalisme Sensitif Bencana dalam Manajemen Pencarian, Pengelolaan Informasi dan Pemberitaan Bencana di Ruang Redaksi. Jurnal ASPIKOM. https://doi.org/10.24329/aspikom.v3i4.185

Sunarti, S. (2013). Kajian Lintas Media. Jakarta: Kepustakaan Populer Gramedia.

Susanto, E. H. (2011). Komunikasi Bencana dan Bencana Komunikasi. In A. Ishak, Aswad; Junaedi, Fajar; HH, Setio Budi; Prabowo (Ed.), Komunikasi Bencana (pp. ix-xii). ASPIKOM.

Wendratama, E. (2017). Jurnalisme Online. Yogyakarta: Bentang Pustaka.

Zaller, J. (2003). A New Standard of News Quality. Political Communication Journal, 20, 109-130. 